\title{
Soledad Pérez de Ayala Becerril (1976-2011), in memoriam
}

\author{
Paloma TEJADA CALLER \\ Universidad Complutense de Madrid
}

Soledad Pérez de Ayala Becerril, a colleague Lecturer in the Department of English Language and Linguistics at the Universidad Complutense de Madrid, died last February. Sole devoted her academic life to the study of Pragmatics, published her successful doctoral dissertation on Parliamentary Question Time as "Cortesía e imagen en el Parlamento británico: Question Time», and contributed insightful articles to national and international conferences on English Linguistics. She was attested a much beloved, welcoming, bright and efficient teacher, able to lead students into the most hidden details of verbal communication. And we all felt admired at her individual charm, delicate grace and unaffected refinement. She left too young, but acquainted of all wisdom. Because Sole lived two parallel lives, incarnated two chronological ages and embodied two kinds of knowledge. Her illness deprived us of further learned and scholarly deep pragmatic findings. She left much unsaid, implicit and untaught. But personally she rubbed shoulders with the wisest and most learned. Basic knowledge, be it human or scientific, is desirably said to be a public commodity, freely-accessed. And Sole socialized her innermost learning; the experience she herself had gained, as she went through her single and unique conflicts, regardless universal, the route maps, preferred trails and prelacies she found most useful to configure her difficult programme of growth and understanding. This way she related her erudition to our lives as individual human beings, to our social and cultural community. She had her soul "intoxicated with love", she could read what "the hand of Death had written on her forehead", she could show "the dawn of hope in her eyes", with its "magic meaning", she had learnt that she would never "be a slave of life", that "Death is a queer time", "unnatural" and "of unduly violence", that "no man is an island", but "part of the main", that "only the gentle are truly strong" and that "attitude is more important than facts". She taught us to "dry our tears and raise our heads as the flowers raise their crowns to greet the dawn", to look "between her bed and the infinite"; she understood that "Death is a Dialogue between The Spirit and the Dust", "Dissolve" says Death -- The Spirit "Sir I have another Trust" -. She could appreciate the wisdom of flowers, knowing "to be white when jasmines and velvet when lilies", "¡Cuánto sabe la flor! Sabe el silencio; y teniendo unos labios tan hermosos sabe callar el "jay!" y el "no", e ignora la negativa y el sollozo". She claimed that 
"parting is such sweet sorrow", that she would only "say good night till ... tomorrow". "Her bones tailored to her pains" and her "forehead to her thoughtfulness", she felt unworried about her own substance, lived in her acts: "por esta calle que vamos me han dicho que no hay salida; yo la tengo que encontrar aunque me cueste la vida". With the tip of her fingers, "she played the strings of the world, and made them sing of dawns, triumphs, colours, joys, it was her music". Sole, "alma ausente", she had the noble maturity of knowledge. That is why we will always be seated "en las vagas lindes de su alma". She left the world a better place. This is to have succeeded. 